\title{
The SNAIL AND THE Ginger BEER: THE Singular CASE OF DONOGHUE V STEVENSON, MATTHEW CHAPMAN (LONDON: WILDY, SiMMONDS \& HILL, 2010)
}

When I first saw The Snail and the Ginger Beer, ${ }^{1}$ I was attracted more by its jacket (featuring a rather lively snail, tentacles extended) and title (most Holmesian, my dear Watson!) than by any expectation of what it might teach me about the case that heralded the modern law of negligence throughout the Commonwealth world. With all that has been written about Donoghue $v$ Stevenson, ${ }^{2}$ could there be anything more to tell about the shocking case of gastroenteritis caused, it is said, by gastropod detritus lingering in some ginger beer? ${ }^{3}$ Well, yes, actually, and Matthew Chapman has done an excellent job in the telling. Chapman, a London barrister, has produced a well-researched and pithily presented story, not only of the case itself, but of the legal-historical context leading up to it and, to a lesser extent, its fate since being decided by a 3:2 majority of the House of Lords in 1932.

Snail begins by recounting the factual setting, including what little we know about the Scottish pursuer and defender, May Donoghue and David Stevenson. We learn something of ginger beer's popularity at the time (the cloudiness and natural sedimentation of which influenced the opaque bottle design that was to be a linchpin in the case), the manufacturing processes for returning and refilling bottles (gaps in those processes may have been open invitations to curious snails), and some delightful trivia on the genus Helix. This is followed by a précis of the litigation in the Scottish courts, including the two preceding Barr ${ }^{4}$ cases in which the courts had made factual findings that there had been dead mice in the pursuers' ginger beer bottles, but in which the Second Division of the Court of Session had nevertheless held, 3:1, that the manufacturers owed the pursuers no duty of care, absent privity of contract. ${ }^{5}$

As Chapman notes, Barr was hardly a "happy omen"“ for Donoghue, whose case was filed only three weeks later. That it was filed at all is a testament to the fortitude - and, dare we say, sense of injustice - of Donoghue's solicitor, Walter Leechman, who was well aware of the state of the law, having been the agent for the pursuers' solicitors in Barr. Following some interlocutory skirmishing, the first instance judge, Lord Moncrieff, found for Donoghue, making him the case's "unsung hero,"7 albeit by some fancy judicial footwork that Chapman details. Little surprise, then, that when Donoghue was appealed to the same panel that had decided Barr, the majority opinion was the same: "[T]he only difference," said Lord Alness, "is that there we were dealing with a mouse in a ginger-beer bottle, and here

Matthew Chapman, The Snail and the Ginger Beer: The Singular Case of Donoghue v Stevenson (London: Wildy, Simmonds \& Hill, 2010) [Snail].

Donoghue v Stevenson, [1932] AC 562 (HL) [Donoghue].

Said, that is, by my colleague D Michael Bain in his parodic song, Mollusc in a Bottle. To Bain must go the lyrical credit of conjoining gastropod detritus with gastroenteritis: the Donoghue pleadings, our only source of knowledge for the alleged facts, are strictly prosaic.

Mullen v AG Barr \& Co; M’Gowan v AG Barr \& Co, [1929] SC 461 (Ct Sess) [Barr].

Ibid at 469.

Snail, supra note 1 at 19.

Scottish Council of Law Reporting (SCLR), “Lord Moncrieff, the Unsung Hero” (2008), online: SCLR <http://www.scottishlawreports.org.uk/resources/dvs/lord-moncrieff.html>. This website is a valuable resource for the Donoghue case and includes digitized images of the original appeal papers. 
we are dealing with a snail in a ginger-beer bottle. Quoad ultra the circumstances appear to be identical." 8

On, then, to the House of Lords, the setting in which most law students learn about the case. While we will never know what was said in the two-day hearing, the appeal papers indicate just how narrowly the case was argued and how much the argument for both sides turned on precedent. Donoghue's counsel, for example, referred to only seven cases in written argument, his boldest assertion being that "[n]o case can be found where in circumstances similar to the present the Court has held that the manufacturer is under no liability to the consumer." "While this low-key approach may have reflected a strategy of pursuing the line of least resistance (and resistance they surely met in Lord Buckmaster's scathing reaction), Lords Atkin and MacMillan had a grander scheme in mind, one that would clear a path through the "wilderness of single instances"10 that negligence law had become. They were therefore left to their own devices in formulating the grander statements of policy and principle that made the case so famous. The grandest of those statements is, of course, Lord Atkin's neighbour principle:

You must take reasonable care to avoid acts or omissions which you can reasonably foresee would be likely to injure your neighbour. Who, then, in law is my neighbour? The answer seems to be-persons who are so closely and directly affected by my act that I ought reasonably to have them in contemplation as being so affected when I am directing my mind to the acts or omissions which are called in question. ${ }^{11}$

The part of Snail that I found most intriguing was Chapman's tracing of this principle, not only to the biblical roots that Lord Atkin alludes to elsewhere in his speech, ${ }^{12}$ but also to the common law. This law included early cases in which defendants had objected to writs framed as actions on the case rather than in trespass, an example being Star $v$ Rookesby, ${ }^{13}$ where the defendant's cattle had escaped through a fence onto the plaintiff's land, causing damage. The Court said that either action would lie in: "trespass, because it was the plaintiff's ground and not the defendant's; and case, because the first wrong was a nonfeasance and neglect to repair [the fence], and that omission is the gist of the action; and the trespass is only consequential damage." ${ }^{14}$ Apparently, things had crystallized to the point where, by the mid-

Snail, supra note 1 at 29, citing the earlier Donoghue case from the Second Division of the Court of Session contained in "Opinions of the Judges of the Second Division of the Court of Session, delivered when giving Judgment on 13th November 1930,” Ref No HL/PO/JU/4/3/873, 21 at 22.

$9 \quad$ Snail, supra note 1 at 36.

10 The phrase is from Tennyson's 1864 poem “Aylmer's Field,” reprinted in Christopher Ricks, ed, The Poems of Tennyson (London: Longmans, Green, 1969) 1159 at 1172. The poem's protagonist, Leolin, has gone off to study law, the prospect of which is daunting to the extreme (lines 432-39):

So Leolin went; and as we task ourselves

To learn a language known but smatteringly

In phrases here and there at random, toiled

Mastering the lawless science of our law,

That codeless myriad of precedent,

That wilderness of single instances,

Through which a few, by wit or fortune led,

May beat a pathway out to wealth and fame.

Donoghue, supra note 2 at 580.

Ibid.

(1710), 91 ER 295 [Star].

Snail, supra note 1 at 85, citing Star, ibid at 295 [emphasis added]. 
1700s, the author of An Introduction to the Law Relative to Trials at Nisi Prius ${ }^{15}$ was able to state a nascent version of the neighbour principle: "Every Man ought to take reasonable Care that he does not injure his Neighbour; therefore, whereever a Man receives any Hurt through the Default of another, though the same were not wilful, yet if it be occasioned by Negligence or Folly, the Law gives him an Action to recover Damages for the Injury so sustained." 16 This proposition was followed by various instances from the cases, but the context makes clear that they were meant to exemplify a general principle rather than set out specific categories of negligence. The drive to categorization, though, is what followed, so much so that by a century later, a leading text listed 56 duties of care, one of which had to match the facts of a case, and absent which a plaintiff was without a cause of action. ${ }^{17}$ In this golden age of contract, judges were especially vigilant about tort's perceived incursions into the domain of contract. Thus, where a coach driver was injured due to latent defects in a coach, he could not sidestep his employer (who had contracted with the coach owner) and sue the owner directly, for "[u]nless we confine the operation of such contracts as this to the parties who entered into them, the most absurd and outrageous consequences ... would ensue."18 The few decisions that took a less parsimonious approach were treated as anomalies or distinguished to the point of being sidelined. ${ }^{19}$ Donoghue finally broke this legal ossification; in this regard, Lord Macmillan's announcement that "[t]he categories of negligence are never closed" ${ }^{20}$ was a neat foil to Lord Buckmaster's rigid adherence to precedent, ranking as importantly, if not as eloquently, as Lord Atkin's articulation of the neighbour principle.

Canadian readers will appreciate Chapman's reference to the early Canadian cases, which, along with Associate Judge Cardozo's (as he was then) leading opinion in MacPherson v Buick Motor Company, ${ }^{21}$ formed a corpus of North American judgments that prefigured Donoghue by as much as a couple of decades. Indeed, the book inspired me to go back and read these cases myself to glean more from their history than Snail provides.

The first of these, Dominion Natural Gas Company v Collins \& Perkins, ${ }^{22}$ involved an explosion that killed one man and seriously injured another. A jury found that the explosion was caused by the negligence of a gas company's employees, who failed to properly connect a safety valve to a roof vent. The decision was upheld by the Ontario Court of Appeal, from which the gas company appealed by special leave to the Judicial Committee of the Privy Council. The Privy Council affirmed the decisions below, and while the judgment can be partly understood to be based on the notion of gas as an imminently dangerous substance (such as a recognized category giving rise to a specific duty of care), the Privy Council also put the case on a broader footing:

The treatise is believed to have been authored by Lord Bathurst, England's Solicitor General, Attorney General, and eventually, Lord Chancellor. It later became a standard text. The fifth edition has been digitized and is available online: Francis Buller, An Introduction to the Law Relative to Trials at Nisi Prius, 5th ed (London, 1788), online: Google <http://www.books.google.com>.

Ibid at 25.

Snail, supra note 1 at 89, citing Thomas Beven, Principles of the Law of Negligence (London: Stevens and Haynes, 1889).

Snail, supra note 1 at 91, citing Winterbottom $v$ Wright (1842), 10 M \& W 109 at para 114.

See especially the Court of Exchequer's decision in George and Wife v Skivington (1869), LR 5 Ex 1

[Skivington] and Brett MR's judgment in Heaven v Pender (1883), 11 QBD 503 (CA) [Heaven].

Donoghue, supra note 2 at 619.

(1916), 217 NY 382 (CA) [MacPherson].

[1909] AC 640 (Ont PC). 
The gas company were not the occupiers of the premises [thus negating occupier's liability].... Further, there being no relation of contract between the company and the plaintiffs, the plaintiffs cannot appeal to any defect in the machine ... which might constitute breach of contract. There may be, however, in the case of any one performing an operation, or setting up and installing a machine, a relationship of duty. What that duty is will vary according to the subject-matter of the things involved. ${ }^{23}$

The Privy Council was composed, as most will know, of some of the same Law Lords who sat on the Appellate Committee of the House of Lords. Thus, as early as 1909, there was evidence that at least some Law Lords thought that a duty of care could exist independently of contract, and that the relation of duty could vary with the context.

Then, in 1919, Justice Drysdale held for a Nova Scotia plaintiff, Buckley, who had bought a Mott's chocolate bar, only to learn that the bar contained ground glass. ${ }^{24}$ This learning apparently took place only after the whole bar had been consumed — with injurious results to Buckley's alimentary canal. As in so many cases, the bar had been bought from a retailer interposed between plaintiff and defendant, so there was no contractual privity between those two. Justice Drysdale agreed that the plaintiff was a stranger to the contract and could not sue on it, but concluded that a tortious duty of care had long been "engrafted" onto contract law, sufficient to hold Mott liable in negligence. ${ }^{25}$

Then, two years later, Ross v Dunstall ${ }^{26}$ reached the Supreme Court of Canada. It was about the manufacture of bolt action rifles, which, when reassembled by buyers after cleaning, became dangerously defective. The evidence was that the rifles were in excellent condition when sold, but after cleaning, had to be reassembled — but the manufacturer gave no instructions as to how to do this. A buyer would be injured when the rifle bolt was driven back through the breach while being fired. The case was decided under the Civil Code of Québec, ${ }^{27}$ but the Court's interpretation of the relevant Code provision was strongly influenced by common law jurisprudence, especially Skivington, ${ }^{28}$ Heaven, $^{29}$ and MacPherson. ${ }^{30}$ Consider first this excerpt of Justice Anglin decision: "The law cannot be so impotent as to allow ... a manufacturer to escape liability for injuries — possibly fatal — to a person of a class who he contemplated would use his product in the way in which it was used caused a latent source of danger which reasonable care on his part should have discovered and to give warning of which no steps have been taken”31 and compare it to Lord Atkin's hypothetical, followed by his statement of the manufacturer principle (the other ratio decidendi in Donoghue):

A manufacturer puts up an article of food in a container which he knows will be opened by the actual consumer. There can be no inspection by any purchaser and no reasonable preliminary inspection by the consumer. Negligently, in the course of preparation, he allows the contents to be mixed with poison. It is said

Ibid at 646 [emphasis added].

Buckley $v$ Mott (1919), 50 DLR 408 (NSSC).

Ibid at 409.

[1921] 62 SCR 393 [Ross].

SQ 1991, c 64 [Code].

Supra note 19.

Supra note 19.

Supra note 21.

Ross, supra note 26 at 403. 
that ... the poisoned consumer has no remedy against the negligent manufacturer. If this were the result of the authorities, I should consider the result a grave defect in the law.

My Lords, ... a manufacturer of products, which he sells in such a form as to show that he intends them to reach the ultimate consumer in the form in which they left him with no reasonable possibility of intermediate examination, and with the knowledge that the absence of reasonable care in the preparation or putting up of the products ... owes a duty to the consumer to take that reasonable care. ${ }^{32}$

Ergo, Chapman finds it "tempting to conclude that the judges in Canada (and, for that matter, the United States) had ... quietly resolved the Donoghue v Stevenson conundrum many years before the English/Scottish courts managed to do the same."33

Chapman's treatment of the post-Donoghue case law is, by his own admission, selective. He traces the United Kingdom's path through Hedley Byrne Ltd v Heller \& Partners ${ }^{34}$ (reproducing Lord Devlin's dense but important formula on how to avoid error when applying the neighbour principle), Home Office v Dorset Yacht Company, ${ }^{35}$ Anns v Merton London Borough Council, ${ }^{36}$ and, finally, the recanting of the two-stage Anns test (presumptive duty of care based chiefly on foreseeability, rebuttable with policy factors tending to negate liability) by the House of Lords in Murphy v Brentwood District Council ${ }^{37}$ and its rejection by the High Court of Australia in Sutherland Shire Council v Heyman. ${ }^{38}$ This recanting and rejection was based on a reading of Anns as being far too expansive because of its seeming abandonment of proximity as an independent criterion from foreseeability when deciding whether a duty of care exists. I wish, though, that Chapman had also shown how Canadian and New Zealand courts, far from shunning Anns, have embraced and adapted it, applying it with little difficulty to the same type of negligent building inspection case that arose in Anns but that so alarmed the Law Lords in Murphy. ${ }^{39}$ Quite simply, courts in these countries read Anns differently, and their readings have hardly led to the proverbial floodgates of litigation being thrown open. ${ }^{40}$ This divergence in practice is a useful reminder that negligence law depends vitally, and will continue to depend, on the policy choices of courts at least as much as it does on their ability to manipulate legal rules.

I recommend The Snail and the Ginger Beer to anyone wanting to engage in a fascinating legal story, especially those interested in the historical development of tort law. While much of Chapman's research is based on secondary sources, it is a unique companion to those sources and draws on Chapman's original research, including close attention to the appeal

Donoghue, supra note 2 at 582, 599.

Snail, supra note 1 at 147-48.

[1964] AC 465 (HL).

[1970] AC 1004 (HL).

[1978] AC 728 (HL) [Anns].

[1991] 1 AC 398 (HL) [Murphy].

(1985), 60 ALR 1 (HCA).

In Canada, see Kamloops (City of) v Nielsen, [1984] 2 SCR 2. In New Zealand, see North Shore City Council v Body Corporate 188529 (Sunset Terraces), [2010] NZSC 158, affirming the Privy Council's decision in Invercargill City Council v Hamlin, [1996] 1 NZLR 513.

40 In Canada, see the companion decisions of Cooper v Hobart, [2001] 3 SCR 537; Edwards v Law Society of Upper Canada, [2001] 3 SCR 562. 
papers and high quality reproductions of portraits of the key judges in the case, some previously unpublished. The photos even include an older May Donoghue, holding her twin granddaughters 30 years after the case - well recovered from her shocking case of gastroenteritis.

John C. Kleefeld

Assistant Professor

College of Law

University of Saskatchewan 